Research Article

\title{
Zircon U-Pb Dating and Lu-Hf Isotope of the Retrograded Eclogite from Chicheng, Northern Hebei Province, China
}

\author{
Xu Kong, ${ }^{1}$ Xueyuan $Q i{ }^{2}$ Wentian Mi $\mathbb{D},{ }^{2,3}$ and Xiaoxin Dong ${ }^{2}$ \\ ${ }^{1}$ Department of Geology, Northwest University, Xi'an 710069, China \\ ${ }^{2}$ Inner Mongolia University of Technology, Hohhot 010051, China \\ ${ }^{3}$ Key Laboratory of Western China's Mineral Resources of Gansu Province, Lanzhou University, Lanzhou 730000, China
}

Correspondence should be addressed to Wentian Mi; miwentian1982@imut.edu.cn

Received 7 April 2021; Revised 26 April 2021; Accepted 3 June 2021; Published 17 June 2021

Academic Editor: Xiaowei Feng

Copyright (c) $2021 \mathrm{Xu}$ Kong et al. This is an open access article distributed under the Creative Commons Attribution License, which permits unrestricted use, distribution, and reproduction in any medium, provided the original work is properly cited.

\begin{abstract}
We report zircon $\mathrm{U}-\mathrm{Pb}$ ages and Lu-Hf isotopic data from two sample of the retrograded eclogite in the Chicheng area. Two groups of the metamorphic zircons from the Chicheng retrograded eclogite were identified: group one shows characteristics of depletion in LREE and flat in HREE curves and exhibit no significant Eu anomaly, and this may imply that they may form under eclogite facies metamorphic condition; group two is rich in HREE and shows slight negative Eu anomaly indicated that they may form under amphibolite facies metamorphic condition. Zircon Lu-Hf isotopic of $\varepsilon \mathrm{Hf}$ from the Chicheng eclogite has larger span range from 6.0 to 18.0, which suggests that the magma of the eclogite protolith may be mixed with partial crustal components. The peak eclogite facies metamorphism of Chicheng eclogite may occur at 348.5-344.2 Ma and its retrograde metamorphism of amphibolite fancies may occur at ca. 325.0 Ma. The Hongqiyingzi Complex may experience multistage metamorphic events mainly including Late Archean (2494-2448 Ma), Late Paleoproterozoic (1900-1734 Ma, peak age = 1824.6 Ma), and Phanerozoic $(495-234 \mathrm{Ma}$, peak age $=323.7 \mathrm{Ma})$. Thus, the metamorphic event $(348.5-325 \mathrm{Ma})$ of the Chicheng eclogite is in accordance with the Phanerozoic metamorphic event of the Hongqiyingzi Complex. The eclogite facies metamorphic age of the eclogite is in accordance with the metamorphism (granulite facies or amphibolite facies) of its surrounding rocks, which implied that the tectonic subduction and exhumation of the retrograded eclogite may cause the regional metamorphism of garnet biotite plagioclase gneiss.
\end{abstract}

\section{Introduction}

The tectonic evolution of the central part of the northern margin of the North China Craton has become a hot academic research focus in recent years. As a significant component of the dismembered ophiolite mélange of the Hongqiyingzi Complex [1], the retrograded eclogite which recorded the evolution history of the Paleoasian Ocean has been attracting more and more attention [2-9].

The tectonic evolution of the Chicheng retrograded eclogite can be classified into four stages [10]: (1) the protolith formation stage, (2) the peak eclogite facies stage, (3) the granulite facies stage, and (4) the amphibolite facies stage. Previous chronology studies shows that the metamorphic age of the retrograded eclogite are still under disputes: $325 \mathrm{Ma}$ of SHRIMP zircon $\mathrm{U}-\mathrm{Pb}$ age was recommended as the peak metamorphic age by $\mathrm{Ni}$ et al. [10]; $355 \mathrm{Ma}$ of SHRIMP zircon U-Pb age was proposed as the peak metamorphic age by Kong et al. [11]; 1847-1840 Ma of SIMS zircon $\mathrm{U}-\mathrm{Pb}$ age was recommended as the peak metamorphic age by Liu et al. [1]; $1.85-1.80 \mathrm{Ga}, 460-420 \mathrm{Ma}$, and $360-270 \mathrm{Ma}$ of zircon $\mathrm{U}-\mathrm{Pb}$ age was proposed as the peak metamorphic age, retrograded metamorphic age, and amphibolite fancies metamorphic age, respectively, by Zhang et al. [8].

Because zircon geochemistry and chronology are very effective methods applied to metamorphism chronology research of the eclogite, this paper attempts to provide more zircon $\mathrm{U}-\mathrm{Pb}$ and $\mathrm{Lu}-\mathrm{Hf}$ isotopic composition of the eclogite and may be beneficial to solve these disputes. 


\section{Geological Background and Petrological Characteristics}

The Chicheng area, including Zhenningpu, Luhepu, and Qilidun, is located on the north side of the Chongli-Chicheng Fault, northern margin of the North China Craton (NCC) (Figures 1(a)-1(c)). Retrograded eclogite, which occur as separate tectonic lenses within the Hongqiyingzi Complex, range in size from $1-5 \mathrm{~cm}$ to $30-50 \mathrm{~m}$ and their elongation is consistent with regional schistosity or gneissosity (Figure 2(a))

Based on the differences of the mineral assemblages and the degree of retrograde metamorphism, the retrograded eclogite from Chicheng can be divided into the weakly amphibolitized eclogite and the intensely amphibolitized eclogite [11]. The intensely amphibolitized eclogite are characterized by the existence of amphibole and plagioclase, very little or no omphacite and vermicular symplectite of $\mathrm{Na}$-poor clinopyroxene and plagioclase; garnets are replaced completely by a granular symplectite of amphibole and plagioclase. The weakly amphibolitized eclogite are characterized by the existence of remnant omphacite and vermicular symplectite of Na-poor clinopyroxene and plagioclase.

\section{Sample Descriptions}

The weakly amphibolitized eclogite of sample 160601, from the east of Chicheng town, is fine-medium grained, with a mineral assemblage of omphacite $(60$ vol. $\%)+$ garnet $(13$ vol. $\%)+$ diopside ( 2 vol. $\%)+$ amphibole $(5$ vol. $\%)+$ plagioclase $(15$ vol. $\%)+$ quartz (5 vol.\%). The weakly amphibolitized eclogite of sample 160602 from Luhepu, is medium grained, with a mineral assemblage of omphacite (63 vol. $\%)+$ garnet (12 vol. $\%)+$ diopside (2 vol. $\%)+$ amphibole $(5$ vol. $\%)+$ plagioclase $(15$ vol. $\%)+$ quartz $(5$ vol. $\%)$.

\section{Sample Selection and Analytical Methods}

Two samples (sample 160601 and 160602) of retrograded eclogite from Chicheng were used in this research and were performed by zircon ICP-MS U-Pb dating, zircon Lu-Hf isotopic analysis, and zircon trace elements analysis.

4.1. Zircon Selection and Cathodoluminescence Study. Zircons from sample 160601 and 160602 were sorted in the laboratory of the Hebei Regional Geological Investigation Brigade in Langfang city. First, the rock samples were broken into 80-100 mesh grains; then, the zircons were sorted by conventional magnetic separation and then purified by manual picking under a binocular microscope. Before dating, the purified zircons were mounted in an epoxy resin target and polished to half of their thickness.

4.2. Zircon ICP-MS U-Pb Dating, Lu-HfIsotopic Analysis, and Trace Elements' Analysis. The zircon U-Pb dating of sample 160601 and 160602 was conducted using an Analyte Excite (Bozeman, Montana, USA) $193 \mathrm{~nm}$ Laser ablation system combined with a Nu Plasma II ICP-MS (Wrexham, Wales, UK) at Nanjing FocuMS Technology Co. Ltd. The details of the analytical procedures and methods are similar to the dissertations elaborated by Griffin and Yuan $[12,13]$. The diameter of the ion beam was approximately $32 \mu \mathrm{m}$ at $8 \mathrm{~Hz}$ repetition rate, the depth of the ablation was $20-35 \mu \mathrm{m}$, and the duration of the ablation was 40 seconds. In the process of testing, 1 point of the standard zircons was measured after every 5 points of the purified zircons to control the stability and the accuracy of the ion counts. The uncertainty for each measuring point is $\pm 1 \sigma$, and uncertainty of the final concordia ages is $\pm 1 \sigma$. The isotope ages of ${ }^{206} \mathrm{~Pb} /{ }^{238} \mathrm{U}$ were corrected by standard zircons 91500 (1064 Ma) [14]. Due to the small amount of ${ }^{207} \mathrm{~Pb}$ formed in the Phanerozoic zircons, the ${ }^{206} \mathrm{~Pb} /{ }^{238} \mathrm{U}$ ages were used to constrain the metamorphic ages for the retrograded eclogite, and the detailed U-Pb isotopic dating data are shown in Table 1.

The zircon Lu-Hf isotopic analysis of sample 160601 and 160602 was conducted after the zircon $\mathrm{U}-\mathrm{Pb}$ dating was finished. For instrumental mass bias correction, Hf isotope ratios were normalized to ${ }^{179} \mathrm{Hf} /{ }^{177} \mathrm{Hf}=0.7325$ and $\mathrm{Yb}$ isotope ratios to ${ }^{172} \mathrm{Yb} /{ }^{173} \mathrm{Yb}=1.35274$, and the mass bias behavior of $\mathrm{Lu}$ was assumed to follow that of $\mathrm{Yb}$. Correction for the isobaric interferences of ${ }^{176} \mathrm{Yb}$ and ${ }^{176} \mathrm{Lu}$ with ${ }^{176} \mathrm{Hf}$ utilizes ${ }^{176} \mathrm{Yb} /{ }^{173} \mathrm{Yb}=0.796218$ and ${ }^{176} \mathrm{Lu} /{ }^{175} \mathrm{Lu}=0.02655$ [15]. The Hf isotopic data process details were described by Vervoort et al. [16] and Vervoort [17]. The weighted mean ${ }^{176} \mathrm{Hf} /{ }^{177} \mathrm{Hf}$ ratio of standard zircon 91500 is $0.282303 \pm 28$ $(2 \sigma)$, which is indistinguishable with a weighted mean ${ }^{176} \mathrm{Hf} /$ ${ }^{177} \mathrm{Hf}$ ratio of $0.282307 \pm 31(2 \sigma)$ [18]. The weighted mean ${ }^{176} \mathrm{Hf} /{ }^{177} \mathrm{Hf}$ ratio of standard zircon GJ1 is $0.282017 \pm 26$ $(2 \sigma)$, which is indistinguishable with a weighted mean ${ }^{176} \mathrm{Hf} /$ ${ }^{177} \mathrm{Hf}$ ratio of $0.282013 \pm 19(2 \sigma)$ [19].

Calculation of Hf TDM1 ages is based on a depletedmantle source with present-day ${ }^{176} \mathrm{Hf} /{ }^{177} \mathrm{Hf}=0.28325$, using the ${ }^{176} \mathrm{Lu}$ decay constant $1.867 \times 10^{-11}$ year $^{-1}$ [20]. The zircon trace elements analysis of sample 160601 and 160602 were also performed by ICP-MS at the Nanjing FocuMS Technology Co. Ltd. The testing procedures and parameters are similar to zircon $\mathrm{U}-\mathrm{Pb}$ dating and the analytical error is about $\pm 10 \%$ for light rare Earth elements and $\pm 5 \%$ for the other rare Earth elements.

\section{Results}

5.1. Zircon Trace Elements' Analysis. The chondrite-normalized REE (rare-earth element) patterns of zircon from sample 160601 (Table 2) are characterized by flat HREE curves and no significant Eu anomaly, indicating that the zircon may form under eclogite facies metamorphic conditions (Figure 3(d)). Two groups of the zircon chondritenormalized REE curves from sample 160602 can be distinguished: group one is similar to sample 160601 and characterized by flat HREE curves and exhibit no significant $\mathrm{Eu}$ anomaly, suggesting that the zircon may form under eclogite facies metamorphic conditions (Figure 3(e)); group two (including two spots, spot 1.1 and 3.1) exhibits steep HREE curves and slight negative Eu anomaly (Figure 3(f)) and has characteristics of metamorphic origin in CL images 


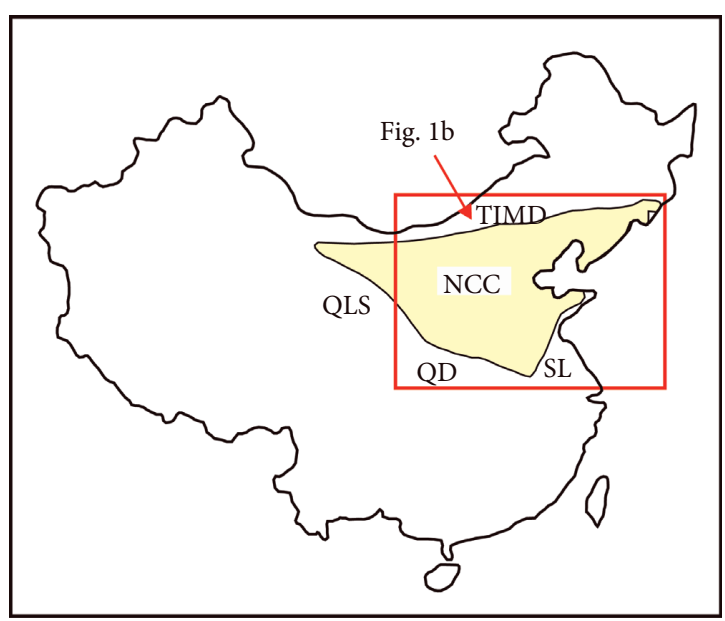

(a)

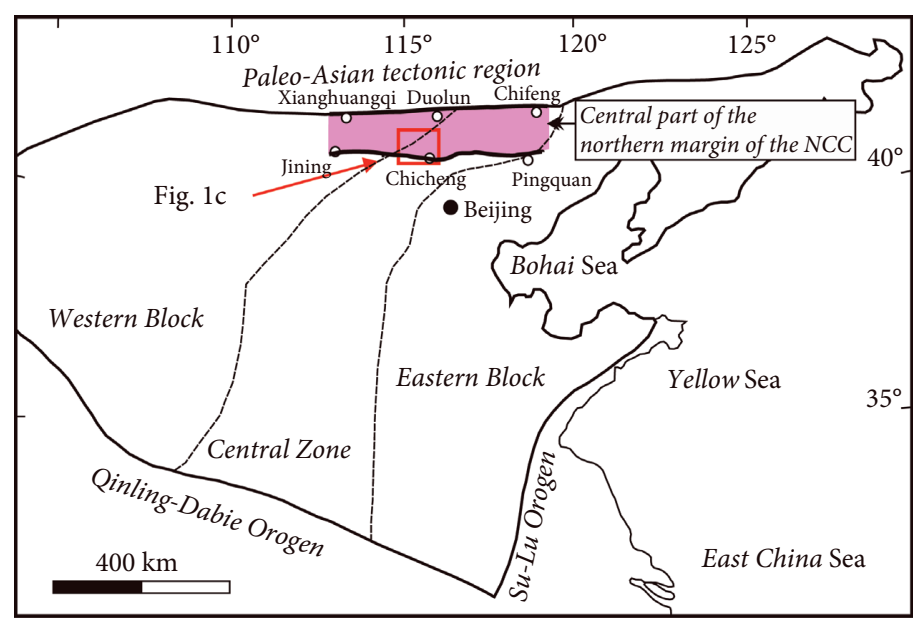

(b)

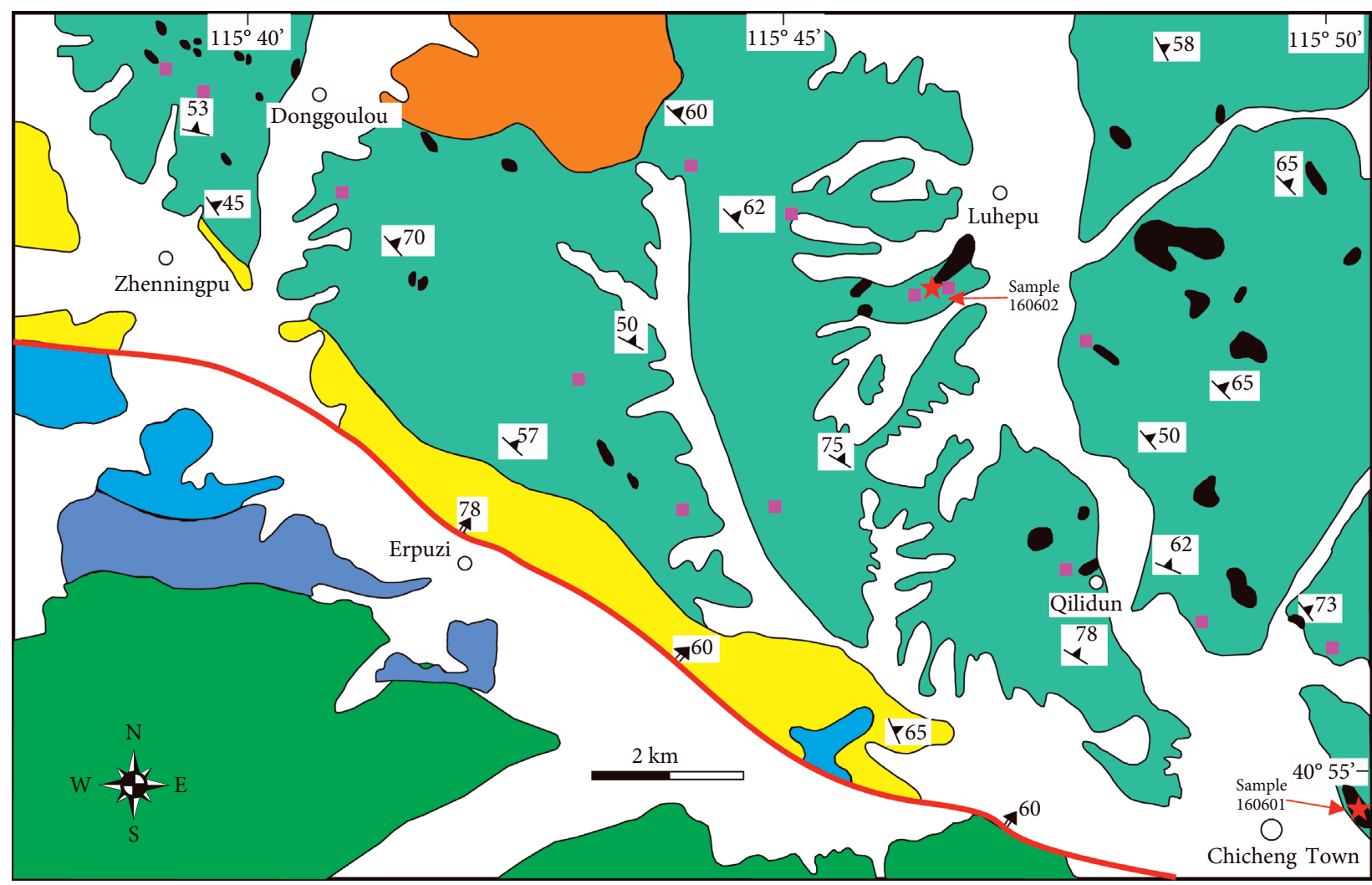

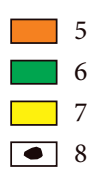

(c)

Figure 1: Geological sketch map showing the location of retrograded eclogite in the Chicheng area, North Hebei Province (modified after [3]). 1 denotes Quaternary cover; 2 denotes Jurassic; 3 denotes Hongqiyingzi complex; 4 denotes Archean rocks; 5 denotes monzonitic granite; 6 denotes porphyritic granite; 7 denotes granitic gneiss-mylonite; 8 denotes metamafic rocks (retrograded eclogite); 9 denotes ultramafic rocks (serpentinized peridotite); 10 denotes Chongli-Chicheng Fault; 11 denotes schistosity; 12 denotes sample location. 


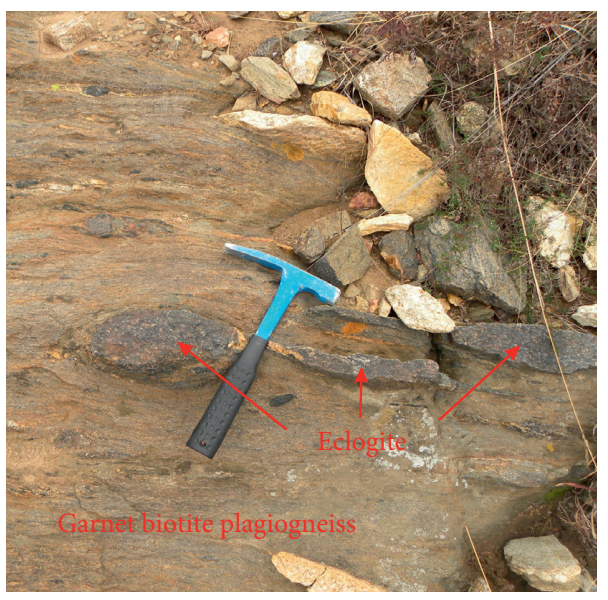

(a)

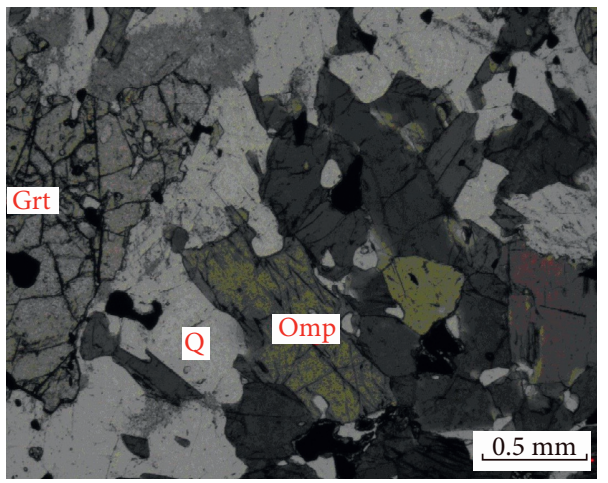

(c)

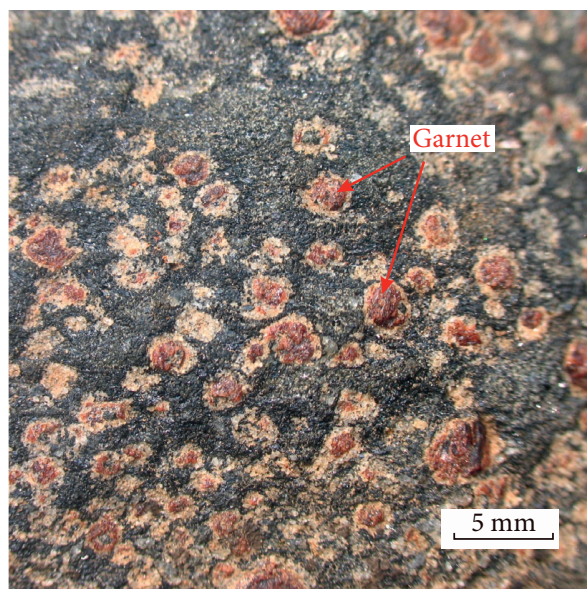

(b)

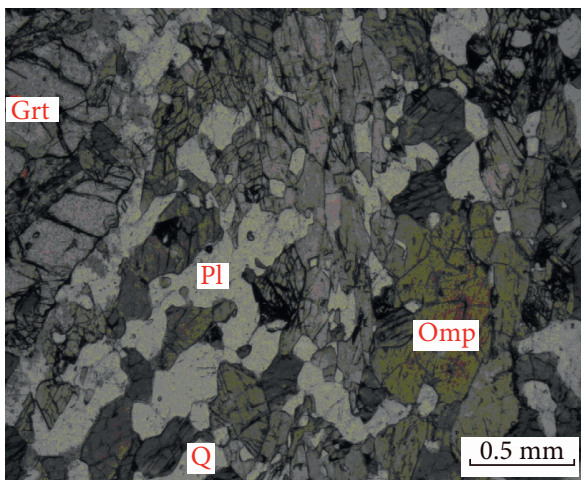

(d)

FIGURE 2: Field photographs and photomicrographs of the retrograded eclogite. (a) The retrograded eclogite occurs as separate tectonic lenses within the Hongqiyingzi Complex. (b) Macrophoto of the symplectite of light-colored minerals around garnet. (c) Photomicrograph of minerals in sample 160602 (single-polarized light). (d) Photomicrograph of minerals in sample 160601 (single-polarized light). Omp: omphacite; Grt: garnet; Pl: plagioclase; Q: quartz.

TABLE 1: Zircon LA-ICP-MS U-Pb geochronological analyses of the eclogite (sample 160601 and 160602).

\begin{tabular}{|c|c|c|c|c|c|c|c|c|c|c|c|c|}
\hline Spot & $\begin{array}{c}\mathrm{Pb} \\
(\mathrm{ppm})\end{array}$ & $\begin{array}{c}\text { Th } \\
(\mathrm{ppm})\end{array}$ & $\begin{array}{c}\mathrm{U} \\
(\mathrm{ppm})\end{array}$ & $\mathrm{Th} / \mathrm{U}$ & $\begin{array}{c}207 \mathrm{~Pb} / \\
235 \mathrm{U}\end{array}$ & $\pm(1 \delta)$ & $\begin{array}{c}206 \mathrm{~Pb} / \\
238 \mathrm{U}\end{array}$ & $\pm(1 \delta)$ & $\begin{array}{c}207 \mathrm{~Pb} / 235 \mathrm{U} \text { age } \\
(\mathrm{Ma})\end{array}$ & $\begin{array}{c} \pm \mathrm{Ma} \\
(1 \delta) \\
\end{array}$ & $\begin{array}{c}206 \mathrm{~Pb} / 238 \mathrm{U} \text { age } \\
(\mathrm{Ma})\end{array}$ & $\begin{array}{c} \pm \mathrm{Ma} \\
(1 \delta)\end{array}$ \\
\hline \multicolumn{13}{|c|}{ Sample 160601} \\
\hline 1.1 & 6.2 & 3.1 & 108 & 0.029 & 0.4104 & 0.0203 & 0.0556 & 0.0009 & 349.2 & 14.6 & 348.6 & 5.2 \\
\hline 2.1 & 4.6 & 0.2 & 73 & 0.003 & 0.4387 & 0.0275 & 0.058 & 0.0012 & 369.3 & 19.4 & 363.7 & 7.1 \\
\hline 3.1 & 6 & 0.2 & 91 & 0.002 & 0.4724 & 0.0236 & 0.058 & 0.001 & 392.9 & 16.3 & 363.6 & 6.0 \\
\hline 4.1 & 16.1 & 1.7 & 280 & 0.006 & 0.4091 & 0.0133 & 0.0559 & 0.0007 & 348.3 & 9.6 & 350.7 & 4.2 \\
\hline 5.1 & 7.7 & 0.6 & 127 & 0.005 & 0.4156 & 0.0194 & 0.0568 & 0.0008 & 352.9 & 13.9 & 356.4 & 5.0 \\
\hline 6.1 & 3.4 & 0.4 & 57 & 0.006 & 0.4247 & 0.0219 & 0.0545 & 0.0008 & 359.4 & 15.6 & 342.1 & 4.8 \\
\hline 7.1 & 6.1 & 0.7 & 106 & 0.006 & 0.4121 & 0.0173 & 0.0561 & 0.0007 & 350.4 & 12.4 & 352.0 & 4.1 \\
\hline 8.1 & 11.7 & 1.4 & 205 & 0.007 & 0.4078 & 0.0112 & 0.055 & 0.0005 & 347.3 & 8.1 & 345.0 & 2.9 \\
\hline 9.1 & 3 & 0.7 & 48 & 0.014 & 0.402 & 0.0205 & 0.0552 & 0.0008 & 343.1 & 14.9 & 346.2 & 5.0 \\
\hline 10.1 & 2.5 & 0.3 & 40 & 0.009 & 0.4293 & 0.0232 & 0.0569 & 0.001 & 362.7 & 16.5 & 356.5 & 5.9 \\
\hline 11.1 & 5.2 & 0.4 & 92 & 0.004 & 0.4042 & 0.0133 & 0.0541 & 0.0006 & 344.7 & 9.6 & 339.4 & 3.4 \\
\hline 12.1 & 1.2 & 0.1 & 20 & 0.004 & 0.4452 & 0.0332 & 0.0569 & 0.0014 & 373.9 & 23.3 & 356.9 & 8.3 \\
\hline 13.1 & 6.2 & 0.8 & 111 & 0.007 & 0.398 & 0.0122 & 0.0543 & 0.0005 & 340.2 & 8.8 & 341.2 & 3.1 \\
\hline 14.1 & 2.6 & 0.4 & 39 & 0.01 & 0.4367 & 0.0243 & 0.0565 & 0.0009 & 367.9 & 17.2 & 354.4 & 5.5 \\
\hline 15.1 & 3.7 & 0.3 & 58 & 0.006 & 0.4577 & 0.021 & 0.0579 & 0.0008 & 382.7 & 14.6 & 362.6 & 5.1 \\
\hline 16.1 & 3.6 & 0.6 & 61 & 0.009 & 0.416 & 0.016 & 0.0556 & 0.0006 & 353.2 & 11.5 & 348.9 & 3.5 \\
\hline 17.1 & 3 & 0.1 & 50 & 0.002 & 0.4143 & 0.0184 & 0.055 & 0.0007 & 352 & 13.2 & 345.1 & 4.2 \\
\hline
\end{tabular}


TABLE 1: Continued.

\begin{tabular}{lcccccccccccc}
\hline Spot & $\begin{array}{c}\mathrm{Pb} \\
(\mathrm{ppm})\end{array}$ & $\begin{array}{c}\mathrm{Th} \\
(\mathrm{ppm})\end{array}$ & $\begin{array}{c}\mathrm{U} \\
(\mathrm{ppm})\end{array}$ & $\mathrm{Th} / \mathrm{U}$ & $\begin{array}{c}207 \mathrm{~Pb} / \\
235 \mathrm{U}\end{array}$ & $\pm(1 \delta)$ & $\begin{array}{c}206 \mathrm{~Pb} / \\
238 \mathrm{U}\end{array}$ & $\pm(1 \delta)$ & $\begin{array}{c}207 \mathrm{~Pb} / 235 \mathrm{U} \text { age } \\
(\mathrm{Ma})\end{array}$ & $\begin{array}{c} \pm \mathrm{Ma} \\
(1 \delta)\end{array}$ & $\begin{array}{c}206 \mathrm{~Pb} / 238 \mathrm{U} \mathrm{age} \\
(\mathrm{Ma})\end{array}$ & $\begin{array}{c} \pm \mathrm{Ma} \\
(1 \delta)\end{array}$ \\
\hline Sample & 160602 & & & & & & & & & & & \\
1.1 & 3.9 & 1 & 59.4 & 0.017 & 0.4743 & 0.034 & 0.0559 & 0.0019 & 337.6 & 9.6 & 324.9 \\
2.1 & 29.3 & 23.5 & 529.5 & 0.044 & 0.3702 & 0.0186 & 0.0525 & 0.001 & 342.9 & 9 & 3.9 \\
3.1 & 30.7 & 22.3 & 562.4 & 0.04 & 0.3714 & 0.0209 & 0.0512 & 0.0012 & 335 & 6.1 & 325.1 \\
4.1 & 23.3 & 2.2 & 413.3 & 0.005 & 0.4263 & 0.0209 & 0.0554 & 0.001 & 360.5 & 7.4 & 347.4 \\
5.1 & 38.5 & 42.9 & 722 & 0.059 & 0.3908 & 0.0168 & 0.0517 & 0.0008 & 341.6 & 10.3 & 333.1 \\
6.1 & 12.7 & 21.2 & 231.8 & 0.091 & 0.3945 & 0.0264 & 0.0517 & 0.0012 & 362.7 & 20.1 & 352.0 \\
7.1 & 8.2 & 1 & 147.3 & 0.006 & 0.3999 & 0.0283 & 0.053 & 0.0011 & 365.2 & 17.7 & 358.3 \\
8.1 & 13.2 & 2.4 & 240.6 & 0.01 & 0.4017 & 0.0248 & 0.0543 & 0.001 & 394.2 & 18.6 & 350.9 \\
9.1 & 4.6 & 1.1 & 81.5 & 0.014 & 0.4146 & 0.0352 & 0.0539 & 0.0016 & 352.2 & 12.6 & 338.4 \\
10.1 & 4.5 & 5.6 & 77.9 & 0.072 & 0.4168 & 0.0382 & 0.0532 & 0.0014 & 353.7 & 13.7 & 33.7 \\
11.1 & 25.5 & 20.3 & 432.9 & 0.047 & 0.4388 & 0.0303 & 0.0556 & 0.0013 & 378.3 & 9.4 & 4.8 \\
\hline
\end{tabular}

(Figure 4), and thus, they may grow under amphibolite facies metamorphic condition [22].

5.2. Zircon $U-P b$ Dating. The zircons from sample 160601 are colorless with subhedral to oval crystals, lengths ranging from 40 to $120 \mu \mathrm{m}$ with length/width ratios of $1: 1$ to $2: 1$ (Figure 4(a)). Cathodoluminescence photos show cloudy zoned or unzoned features for metamorphic zircon. The 17 analytical points were made on this sample, which have similar low Th/U values (0.002-0.029) and yield mean ages of $348.5 \pm 3.7 \mathrm{Ma}$ (Figure $3(\mathrm{a})$ ).

The zircons from sample 160602 are also colorless with subhedral to oval crystals, lengths ranging from 50 to $180 \mu \mathrm{m}$ with length/width ratios of $1: 1$ to $3: 1$ (Figure 4(b)). Cathodoluminescence photos show metamorphic features of nebulous zoned or unzoned. The 9 analytical points of group one zircons have low Th/ $\mathrm{U}$ values $(0.005-0.091)$ and yield mean ages of $344.2 \pm 7.3 \mathrm{Ma}$ (Figure 3(b)). The 2 analytical points of group two zircons have low Th/U values (0.017-0.04) and yield mean ages of 325.0 $\pm 4.1 \mathrm{Ma}$ (Figure 3(c)).

5.3. Zircon Lu-HfDating. Fifteen Lu-Hf spots on the zircon cores were obtained on zircon grains from sample 160601. On the basis of a metamorphic age of approximate $348.5 \mathrm{Ma}$, initial ${ }^{176} \mathrm{Hf} /{ }^{177} \mathrm{Hf}$ ratios and $\varepsilon \mathrm{Hf}(t)$ values are calculated by assuming $t=348.5 \mathrm{Ma}$ (Table 3 ). The metamorphic zircons have a ${ }^{176} \mathrm{Lu} /{ }^{177} \mathrm{Hf}$ ratio of $0.000003-0.000013$ and ${ }^{176} \mathrm{Hf} /$ ${ }^{177} \mathrm{Hf}(348.5 \mathrm{Ma})$ of $0.282726-0.283025$, corresponding to $\varepsilon \mathrm{Hf}$ (348.5 Ma) ranging from 6.0 to 16.6 (Figure 5).

Nine Lu-Hf spots on the zircon cores were obtained on zircon grains from sample 160602. On the basis of a metamorphic age of approximate $344.2 \mathrm{Ma}$, initial ${ }^{176} \mathrm{Hf} /$ ${ }^{177} \mathrm{Hf}$ ratios and $\varepsilon \mathrm{Hf}(t)$ values are calculated by assuming $t=344.2 \mathrm{Ma}$ (Table 3). The metamorphic zircons have a ${ }^{176} \mathrm{Lu} /{ }^{177} \mathrm{Hf}$ ratio of $0.000005-0.000559$ and ${ }^{176} \mathrm{Hf} /{ }^{177} \mathrm{Hf}$ of $0.282921-0.283069$, corresponding to $\varepsilon \mathrm{Hf} \quad(344.2 \mathrm{Ma})$ ranging from 12.8 to 18.0 (Figure 5).

\section{Discussion}

6.1. The Protolith and Metamorphic Condition of the Eclogite. Previous studies shows that the protolith of the Chicheng retrograded eclogite is tholeiitic oceanic crust with geochemical characteristics of midocean ridge basalt (MORB) or island arc tholeiite (IAT) [10] and experiences the peak eclogite facies metamorphism caused by the subduction of Paleo-Asian Ocean crust beneath the NCC and the granulite facies or amphibolite facies metamorphism resulted from its exhumation into the Hongqiyingzi Complex. The peak eclogite facies metamorphism is marked by the existence of a small amount of granular omphacite within the garnets $\left(P>1.40-1.50 \mathrm{GPa}\right.$ and $\left.T=680-730^{\circ} \mathrm{C}\right)$ [10]. These features indicate that the Chicheng eclogite has the oceanic or mantle affinity, and thus, the protolith of the eclogite is of "foreign" origin [23, 24]. Zircon Lu-Hf isotopic of $\varepsilon \mathrm{Hf}$ from the Chicheng eclogite has larger spans range from 6.0 to 18.0 , which suggests that the magma of the eclogite protolith may mix with partial crustal components.

6.2. The Metamorphic Ages of the Eclogite. As presented above, the mineral assemblages from the retrograded eclogite are omphacite, garnet, amphibole, plagioclase, and quartz. Considering the low Th/U ratios and flat HREE curves with no significant Eu anomaly, the zircon age of $348.5 \pm 3.7 \mathrm{Ma}$ from sample 160601 and $344.2 \pm 7.3 \mathrm{Ma}$ from group one of sample 160602 are interpreted as the time of the eclogite facies metamorphism. Due to low $\mathrm{Th} / \mathrm{U}$ ratios and steep HREE curves with slight negative Eu anomaly, the zircon age of $325.0 \pm 4.1 \mathrm{Ma}$ from group two of sample 160602 is interpreted as the time of the retrograde metamorphism of amphibolite facies. The eclogite facies metamorphic age of $348.5-344.2 \mathrm{Ma}$ is older than the previous study of $325 \mathrm{Ma}$ [10] and a little younger than the previous study of $355 \mathrm{Ma}$ (Kong et al. [11]).

6.3. The Relationship of the Metamorphism between the Eclogite and Its Country Rock. According to previous studies, the Hongqiyingzi Complex may experience multistage metamorphic events (Figure 6), mainly including Late Archean (2494-2448 Ma), Late Paleoproterozoic $(1900-1734 \mathrm{Ma}$, peak age $=1824.6 \mathrm{Ma})$, and Phanerozoic $(495-234 \mathrm{Ma}$, peak age $=323.7 \mathrm{Ma})$. The zircon $\mathrm{U}-\mathrm{Pb}$ dating for retrograded eclogite shows that the peak eclogite facies metamorphism may occur at 348.5-344.2 Ma and its retrograde metamorphism of amphibolite fancies may occur at ca. 325.0 Ma. Thus, 


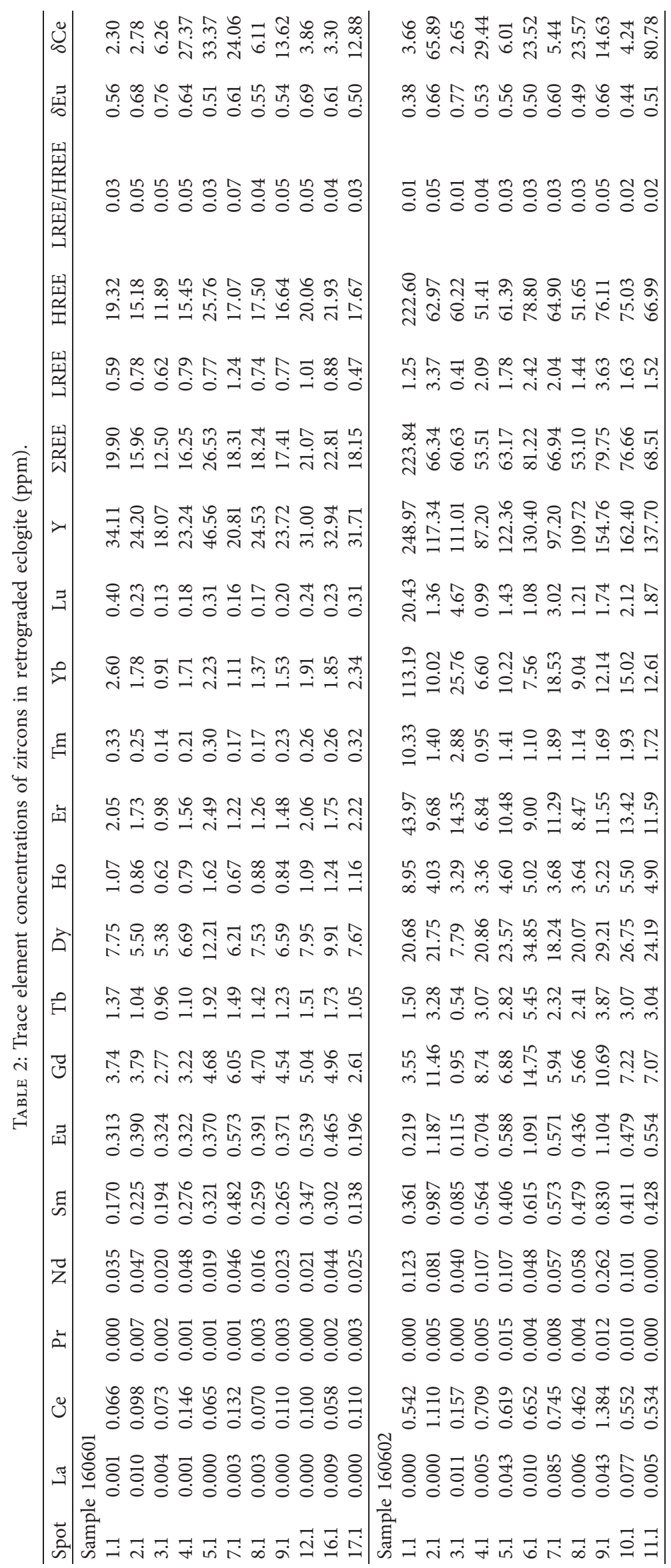




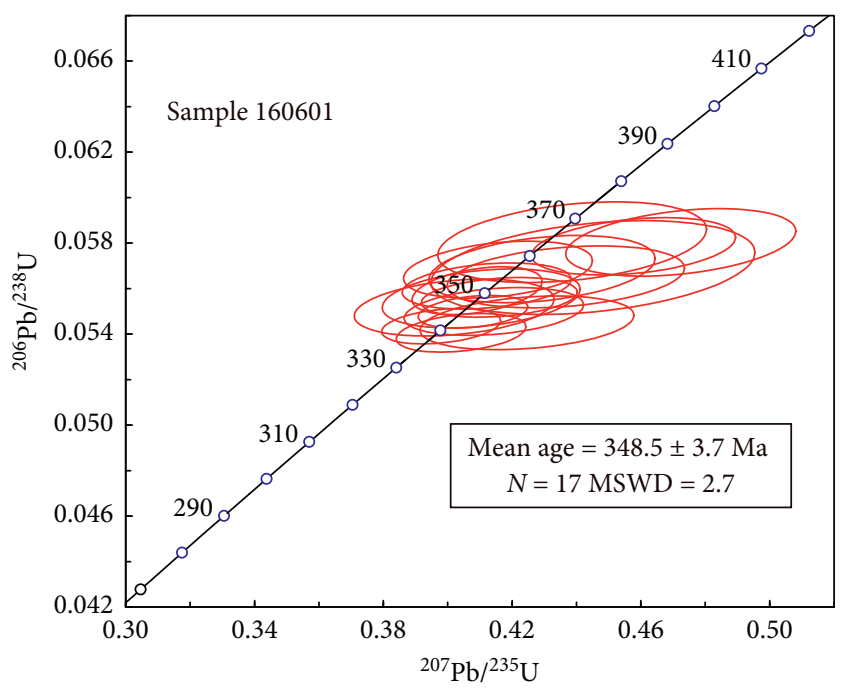

(a)

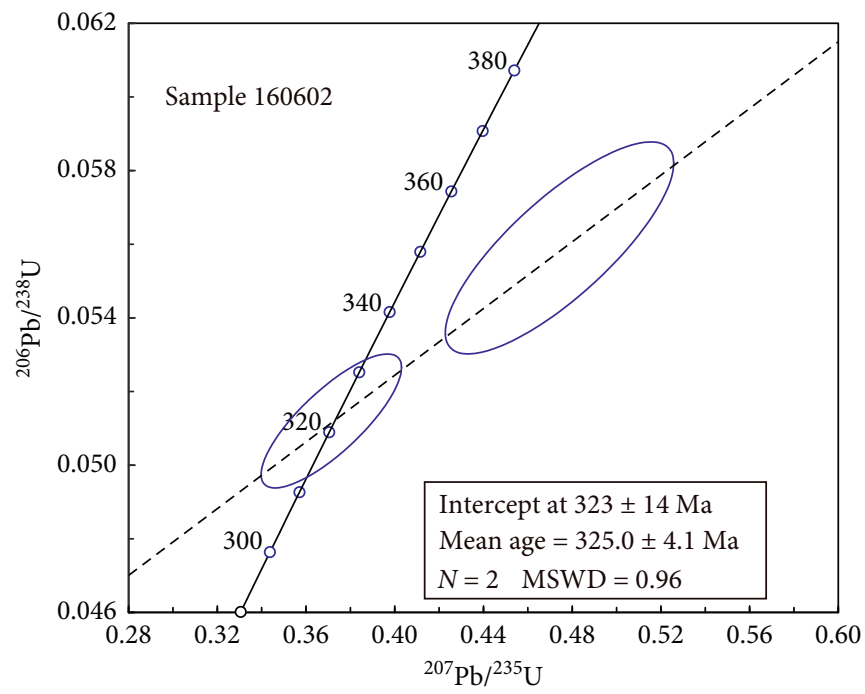

(c)

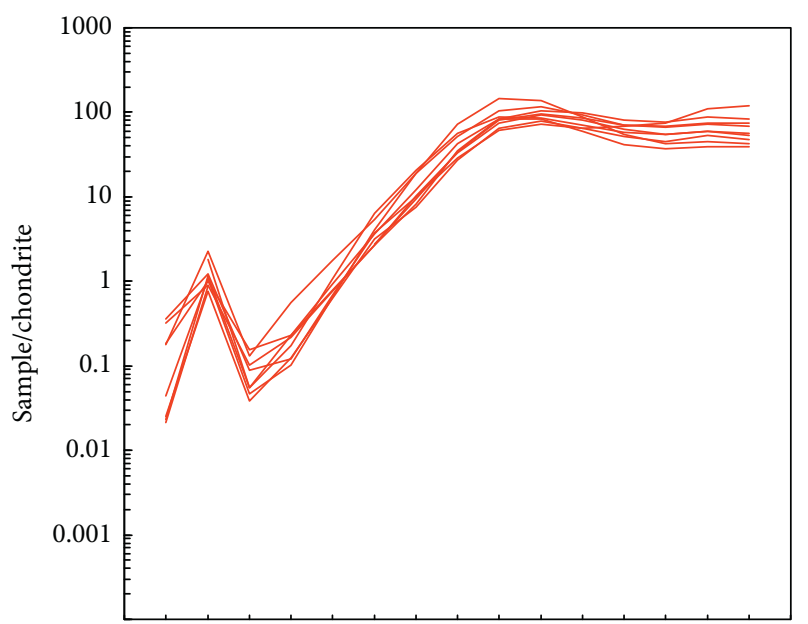

La Ce Pr Nd Eu Sm Eu Gd Tb Dy Ho Er Tm Yb Lu

— Sample 160602 (group one)

(e)

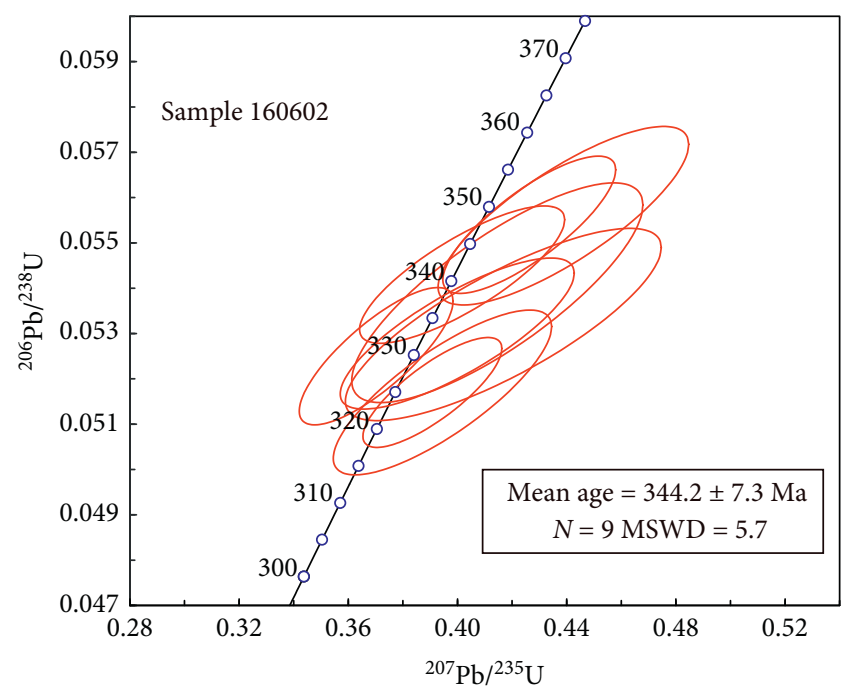

(b)

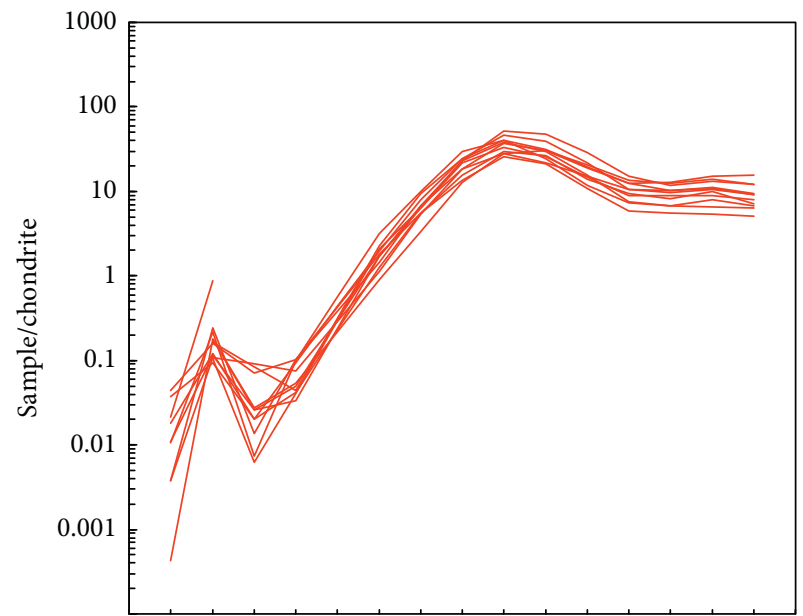

La Ce Pr Nd Eu Sm Eu Gd Tb Dy Ho Er Tm Yb Lu

— Sample 160601

(d)

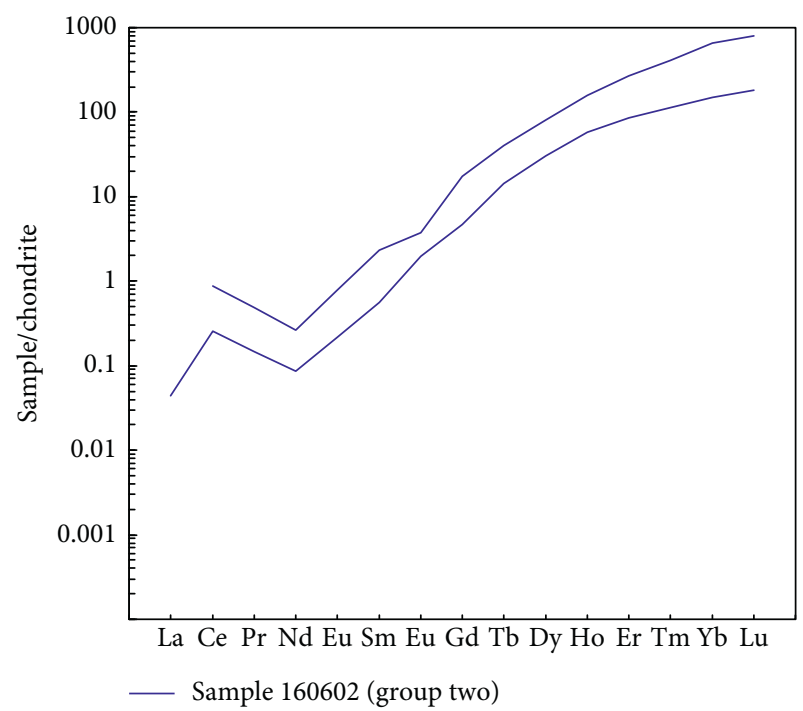

(f)

Figure 3: Concordia plot (Figures (a)-(c)) showing the zircon analysis from the retrograded eclogite. Chondrite-normalized REE plot (Figures (d)-(f)) of the retrograded eclogite from the Chicheng area. The values for chondrite are from [21]. 


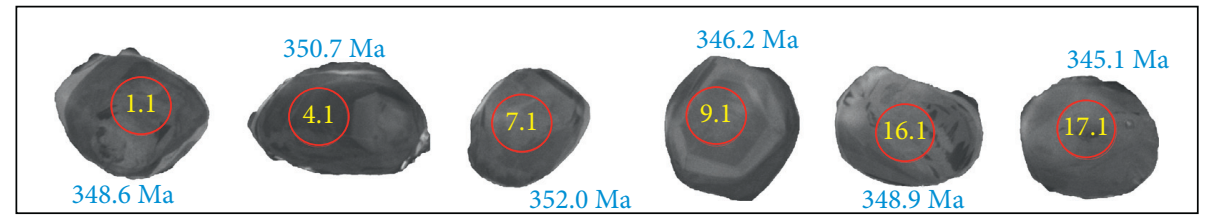

(a)

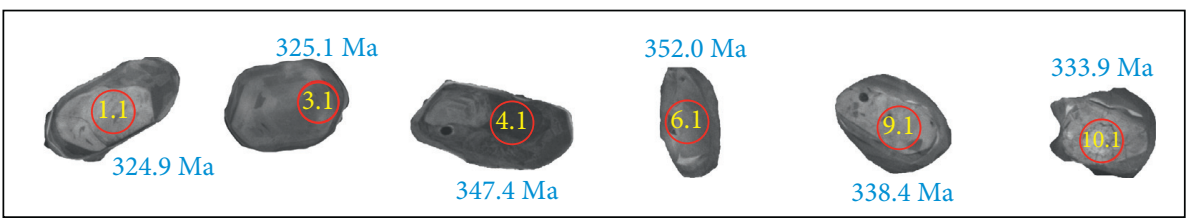

(b)

Figure 4: Cathodoluminescence (CL) images of analyzed zircons from the retrograded eclogite. The red circles represent the sites of analyzed points with diameter of $32 \mu \mathrm{m}$. The ages depicted in the pictures are ${ }^{206} \mathrm{~Pb} /{ }^{238} \mathrm{U}$ ages. (a) 160601. (b) 160602 .

TABLE 3: Isotopic features of zircon Lu-Hf from the retrograded eclogite (sample 160601 and 160602).

\begin{tabular}{|c|c|c|c|c|c|c|c|c|c|c|c|}
\hline Spot & $\begin{array}{c}206 \mathrm{~Pb} / 238 \mathrm{U} \text { age } \\
(\mathrm{Ma})\end{array}$ & $\begin{array}{l}176 \mathrm{Yb} / \\
177 \mathrm{Hf}\end{array}$ & $\pm(2 \delta)$ & $\begin{array}{l}176 \mathrm{Lu} / \\
177 \mathrm{Hf}\end{array}$ & $\pm(2 \delta)$ & $\begin{array}{l}176 \mathrm{Hf} / \\
177 \mathrm{Hf}\end{array}$ & $\pm(2 \delta)$ & $\begin{array}{l}178 \mathrm{Hf} / \\
177 \mathrm{Hf}\end{array}$ & $\pm(2 \delta)$ & $\begin{array}{c}\varepsilon \mathrm{Hf} \\
(t)\end{array}$ & $\begin{array}{l}\mathrm{TDM} \\
(\mathrm{Ma})\end{array}$ \\
\hline \multicolumn{12}{|c|}{ Sample 160601} \\
\hline 1.1 & 348.6 & 0.000269 & 0.000007 & 0.000009 & 0.000000 & 0.282893 & 0.000014 & 1.467956 & 0.000052 & 12.0 & 495.8 \\
\hline 2.1 & 363.7 & 0.000164 & 0.000004 & 0.000004 & 0.000000 & 0.283015 & 0.000008 & 1.467831 & 0.000033 & 16.3 & 326.7 \\
\hline 4.1 & 350.7 & 0.000625 & 0.000011 & 0.000013 & 0.000000 & 0.282726 & 0.000009 & 1.468006 & 0.000031 & 6.0 & 725.8 \\
\hline 5.1 & 356.4 & 0.000306 & 0.000004 & 0.000005 & 0.000000 & 0.282868 & 0.000009 & 1.467985 & 0.000028 & 11.1 & 529.7 \\
\hline 6.1 & 342.1 & 0.000195 & 0.000004 & 0.000004 & 0.000000 & 0.282892 & 0.000007 & 1.468000 & 0.000026 & 11.9 & 497.8 \\
\hline 7.1 & 352.0 & 0.000378 & 0.000008 & 0.000006 & 0.000000 & 0.282869 & 0.000008 & 1.468050 & 0.000027 & 11.1 & 529.0 \\
\hline 8.1 & 345.0 & 0.000678 & 0.000004 & 0.000011 & 0.000000 & 0.282815 & 0.000008 & 1.468060 & 0.000030 & 9.2 & 603.0 \\
\hline 9.1 & 346.2 & 0.000192 & 0.000003 & 0.000004 & 0.000000 & 0.282908 & 0.000007 & 1.468048 & 0.000027 & 12.5 & 475.2 \\
\hline 10.1 & 356.5 & 0.000163 & 0.000003 & 0.000002 & 0.000000 & 0.283025 & 0.0000 & 1.468040 & 0.000 & 16.6 & 312.7 \\
\hline 11.1 & 339.4 & 0.000437 & 0.000003 & 0.000008 & 0.000000 & 0.282961 & 0.000007 & 1.468070 & 0.000 & 14.4 & 402.0 \\
\hline 13.1 & 341.2 & 0.000632 & 0.000004 & 0.000009 & 0.000000 & 0.282997 & 0.000008 & 1.467967 & 0.000026 & 15.6 & 351.7 \\
\hline 14.1 & 354.4 & 0.000129 & 0.000003 & 0.000003 & 0.000000 & 0.282904 & 0.000 & 1.467954 & 0.00 & 12.3 & 480.8 \\
\hline 15.1 & 36 & 0.000326 & & 0.000005 & 0.000 & 0.282962 & & 7977 & & 14.4 & \\
\hline 16.1 & 348.9 & 0.000199 & 0.000003 & 0.000003 & 0.000000 & 0.282952 & 0.000008 & 1.468013 & 0.000024 & 14.0 & 414.0 \\
\hline 17.1 & 345.1 & 0.000173 & 0.000003 & 0.000003 & 0.000000 & 0.282986 & 0.000008 & 1.468018 & 0.000024 & 15.2 & 367.3 \\
\hline \multicolumn{12}{|c|}{ Sample 160602} \\
\hline 2.1 & 340.6 & 0.007992 & 0.000018 & 0.000279 & 0.000001 & 0.283009 & 0.000013 & 1.468003 & 0.000038 & 15.9 & 337.3 \\
\hline 3.1 & 325.1 & 0.015006 & 0.000064 & 0.000559 & & 0.283069 & & 1.468001 & & 18.0 & \\
\hline 4.1 & 347.4 & 0.000633 & 0.000004 & 0.000012 & 0.000000 & 0.282946 & 0.000009 & 1.467974 & 0.000030 & 13.7 & 422.2 \\
\hline 5.1 & 333.1 & 0.012529 & 0.000078 & 0.000313 & 0.000003 & 0.283008 & 0.000012 & 1.467899 & 0.000052 & 15.8 & 340.0 \\
\hline 6.1 & 352.0 & 0.011790 & 0.000083 & 0.000438 & 0.000004 & 0.282982 & 0.000010 & 1.467996 & 0.000036 & 14.9 & 377.1 \\
\hline 7.1 & 358.3 & 0.000262 & 0.000004 & 0.000005 & 0.000000 & 0.282921 & 0.000008 & 1.468039 & 0.000025 & 12.8 & 457.6 \\
\hline 8.1 & 350.9 & 0.001480 & 0.000055 & 0.000043 & 0.000001 & 0.282948 & 0.000009 & 1.468046 & 0.000033 & 13.8 & 420.6 \\
\hline 9.1 & 338.4 & 0.001213 & 0.000023 & 0.000027 & 0.000000 & 0.282974 & 0.000010 & 1.467941 & 0.000034 & 14.7 & 383.7 \\
\hline 10.1 & 333.9 & 0.001200 & 0.000008 & 0.000024 & 0.000000 & 0.282972 & 0.000010 & 1.468016 & 0.000030 & 14.6 & 387.0 \\
\hline
\end{tabular}

the metamorphic event of 348.5-325 Ma from the Chicheng eclogite is in accordance with the Phanerozoic metamorphic event of the Hongqiyingzi Complex. The metamorphism (granulite facies or amphibolite facies) of the eclogite country rock (garnet biotite plagioclase gneiss) occurred from $351 \mathrm{Ma}$ to $343 \mathrm{Ma}$ (our unpublished data). Combined with the fact that the retrograded eclogite occurs as separate tectonic lenses or lumps in the garnet biotite plagioclase gneiss and its major axes direction is in line with regional gneissosity, we come to the conclusion that the tectonic subduction and exhumation of the eclogite may lead to the regional Mesozoic metamorphism of Hongqiyingzi Complex. 


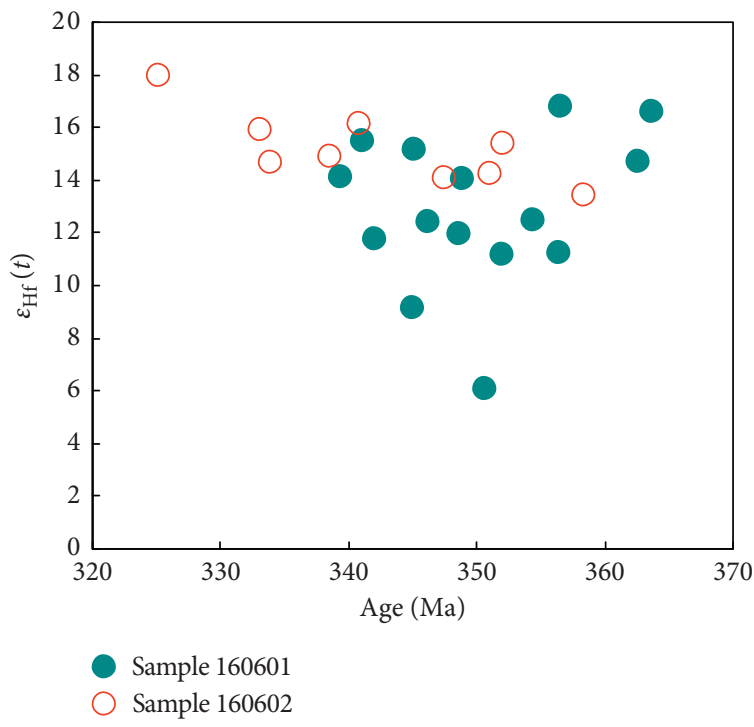

FIGURE 5: The $\varepsilon \mathrm{Hf}^{(t)}$ value of zircons from the retrograded eclogite.

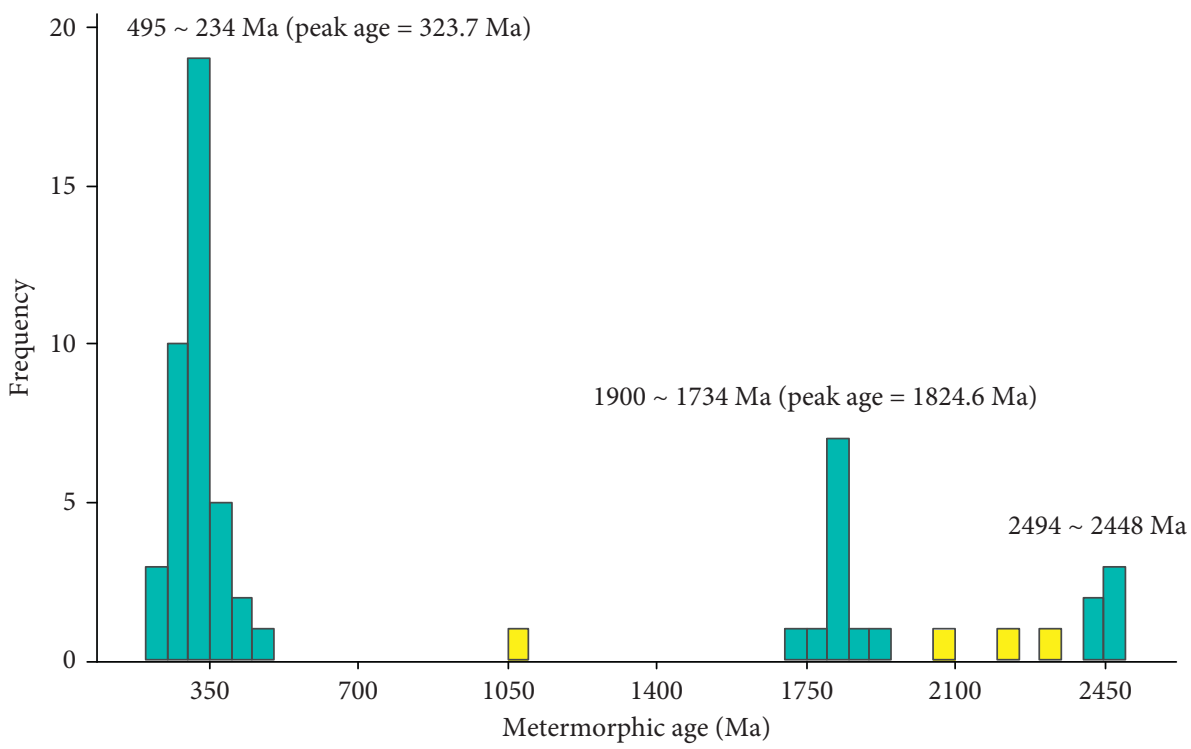

Figure 6: Frequency histogram of metamorphic ages from the Hongqiyingzi complex [1, 2, 7, 8, 10, 11, 25-28].

\section{Conclusions}

(1) Two groups of the metamorphic zircons from the Chicheng retrograded eclogite were identified. Group one shows characteristics of depletion in LREE and flat in HREE curves and exhibit no significant Eu anomaly, and this may imply that they may form under eclogite facies metamorphic condition. Group two is rich in HREE and shows slight negative Eu anomaly and indicate that they may form under amphibolite facies metamorphic condition.

(2) Zircon Lu-Hf isotopic of $\varepsilon \mathrm{Hf}$ from the Chicheng eclogite has larger span range from 6.0 to 18.0 , which suggests that the magma of the eclogite protolith may mix with partial crustal components.
(3) The peak eclogite facies metamorphism of Chicheng eclogite may occur at $348.5-344.2 \mathrm{Ma}$ and its retrograde metamorphism of amphibolite fancies may occur at ca. 325.0 Ma.

(4) The Hongqiyingzi Complex may experience multistage metamorphic events mainly including Late Archean (2494-2448 Ma), Late Paleoproterozoic $(1900-1734 \mathrm{Ma}$, peak age $=1824.6 \mathrm{Ma})$, and Phan erozoic $(495-234 \mathrm{Ma}$, peak age $=323.7 \mathrm{Ma})$. The metamorphic event (348.5-325 Ma) of the Chicheng eclogite is in accordance with the Phanerozoic metamorphic event of the Hongqiyingzi Complex.

(5) The eclogite facies metamorphic age of the eclogite is in accordance with the metamorphism (granulite facies or amphibolite facies) of its surrounding rocks 
and implies that the tectonic subduction and exhumation of the eclogite may lead to the regional metamorphism of garnet biotite plagioclase gneiss.

\section{Data Availability}

The data used to support the findings of this study are included within the article.

\section{Conflicts of Interest}

The authors declare that they have no conflicts of interest.

\section{Authors' Contributions}

Xueyuan Qi \& Xu Kong equally contributed to the work, they are joint first authors.

\section{Acknowledgments}

This study was financially supported by the National Natural Science Foundation of Inner Mongolia (2018LH04006, 2019LH04002, and 2020MS04009) and Foundation of Key Laboratory of Western China's Mineral Resources of Gansu Province in Lanzhou University (Grant no. MRWCGS2019-01), and Key Laboratory of Geoscience Spatial Information Technology of Land and Resources, Chengdu University of Technology, China (KLGSIT2016-02).

\section{References}

[1] H. Liu, H. F. Zhang, and M. Santosh, "Neoarchean growth and paleoproterozoic metamorphism of an archean ophiolite mélange in the north China craton," Precambrian Research, vol. 331, Article ID 105377, 2019.

[2] H. Chu, H. C. Wang, and C. J. Wei, "Geochronology of the paleozoic metamorphism in the Chicheng area, north Hebei, and its geological significance," Acta Geologica Sinica, vol. 87, no. 9, pp. 1233-1246, 2013.

[3] Z. Y. Ni, M. G. Zhai, R. M. Wang, Y. Tong, G. Shu, and X. Hai, "Discovery of late paleozoic retrograded eclogites from the middle part of the northern margin of north China craton," Chinese Science Bulletin, vol. 49, no. 6, pp. 600-606, 2004.

[4] Z. Y. Ni, M. G. Zhai, R. M. Wang, Y. Tong, and Y.-X. Hou, "Pb isotope characteristics of retrograded eclogites from northern Hebei, China," Journal of Chengdu University of Technology (Science \& Technology Edition), vol. 31, no. 2, pp. 125-128, 2004.

[5] Z. Y. Ni, M. G. Zhai, and R. M. Wang, "Retrograded eclogites on the northern margin of north China craton, Hebei province, China: mineral chemistry and retrogressive metamorphism," Acta Mineralogica Sinica, vol. 24, no. 4, pp. 381-390, 2004.

[6] H. F. Zhang, D. Y. Zou, M. Santosh, and B. Zhu, "Phanerozoic orogeny triggers reactivation and exhumation in the northern part of the archean-paleoproterozoic north China craton," Lithos, vol. 261, pp. 46-54, 2016.

[7] J. Zhang, Z. Y. Ni, and M. G. Zhai, "Biotite ${ }^{40} \mathrm{Ar}-{ }^{39} \mathrm{Ar}$ isotopic dating of the biotite plagiogneises from Hongqiyingzi group in Chicheng county, north Hebei, China and its geological implication," Journal of Chengdu University of Technology (Science \& Technology Edition), vol. 39, no. 3, pp. 290-295, 2012.
[8] Y. Y. Zhang, C. J. Wei, and H. Chu, "Paleoproterozoic oceanic subduction in the north China craton: insights from the metamorphic $\mathrm{P}-\mathrm{T}-\mathrm{T}$ paths of the chicheng mélange in the Hongqiyingzi complex," Precambrian Research, vol. 342, Article ID 105671, 2020.

[9] B. Zhou, C. J. Zhang, and Z. Y. Ni, "Geochemistry and protolith of the retrograded eclogite in Chicheng, north Hebei," Acta Geologica Sichuan, vol. 28, no. 4, pp. 339-341, 2008.

[10] Z. Y. Ni, M. G. Zhai, R. M. Wang, and Y. Tong, "Late paleozoic retrograded eclogites from within the northern margin of the north China craton: evidence for subduction of the PaleoAsian ocean," Gondwana Research, vol. 9, pp. 209-224, 2006.

[11] X. Kong, Z. Y. Ni, M. G. Zhai, Y. Shi, G. Yan, and J. Zhang, "Time sequence of evolution for the retrograded eclogite from Chicheng, northern Hebei province: evidence from zircon shrimp U-Pb dating," Mineralogy and Petrology, vol. 31, no. 2, pp. 15-22, 2011.

[12] W. L. Griffin, E. A. Belousova, S. R. Shee, N. J. Pearson, and S. Y. O'Reilly, "Archean crustal evolution in the northern yilgarn craton: U-Pb and Hf-isotope evidence from detrital zircons," Precambrian Research, vol. 131, pp. 231-282, 2004.

[13] H. L. Yuan, S. Gao, X. M. Liu, H. Li, D. Gunther, and F. Wu, "Accurate $\mathrm{U}-\mathrm{Pb}$ age and trace element determinations of zircon by laser ablation-inductively coupled plasma-mass spectrometry," Geostandards and Geoanalytical Research, vol. 28, no. 3, pp. 353-370, 2004.

[14] M. Wiedenbeck, P. Alle, F. Corfu et al., "Three natural zircon standards for U-Th-Pb, Lu-Hf, trace-element and REE analyses," Geostandards Newsletter, vol. 19, pp. 1-23, 1995.

[15] N.-C. Chu, R. N. Taylor, and V. R. Chavagnac, "Hf isotope ratio analysis using multi-collector inductively coupled plasma mass spectrometry: an evaluation of isobaric interference corrections," Journal of Analytical Atomic Spectrometry, vol. 17, pp. 1567-1574, 2002.

[16] J. D. Vervoort, P. J. Patchett, U. Soderlund, and M. Baker, "Isotopic composition of $\mathrm{Yb}$ and the determination of $\mathrm{Lu}$ concentrations and $\mathrm{Lu} / \mathrm{Hf}$ by isotope dilution using MCICPMS," Geochemistry, Geophysics, Geosystems, vol. 5, pp. 1-15, 2004.

[17] J. D. Vervoort, "Lu-Hf dating: the Lu-Hf isotope system," Encyclopedia of Scientific Dating Methods, Springer, Berlin, Germany, 2014.

[18] F. Y. Wu, Y. H. Yang, L. W. Xie, J. H. Yang, and P. Xu, "Hf isotopic compositions of the standard zircons and baddeleyites used in U-Pb geochronology," Chemical Geology, vol. 234, pp. 105-126, 2006.

[19] S. Elhlou, E. Belousova, W. L. Griffin, N. J. Pearson, and S. Y. O'Reilly, "Trace element and isotopic composition of GJred zircon standard by laser ablation," Geochimica et Cosmochimica Acta, vol. 70, no. 18, 2006.

[20] U. Söderlund, P. J. Patchett, J. D. Vervoort, and C. E. Isachsen, "The 176Lu decay constant determined by Lu-Hf and U-Pb isotope systematics of precambrian mafic intrusions," Earth and Planetary Science Letters, vol. 219, pp. 311-324, 2004.

[21] S. S. Sun and W. F. McDonough, "Chemical and isotope systematics of oceanic basalts: implications for mantle composition and processes," in Magmatism in Ocean Basins, A. D. Saunders, Ed., Geological Society Publication, London, UK, 1989.

[22] D. Rubatto, "Zircon trace element geochemistry: partitioning with garnet and the link between $\mathrm{U}-\mathrm{Pb}$ ages and metamorphism," Chemical Geology, vol. 184, pp. 123-138, 2002. 
[23] W. L. Griffin, H. Austrheim, K. Brastad et al., "High-pressure metamorphism in the scandinavian caledonides," in The Caledonide Orogen-Scandinavia and Related Areas, D. G. Gee and B. A. Sturt, Eds., Wiley, Hoboken, NY, USA, 1985.

[24] B. M. Jahn, "Sm-Nd isotope tracer study of UHP metamorphic rocks: implications for continental subduction and collisional tectonics," International Geology Review, vol. 41, pp. 859-885, 1999.

[25] S. W. Liu, J. Fu, Y. J. Lu et al., "Precambrian Hongqiyingzi complex at the northern margin of the north China craton: its zircon $\mathrm{U}-\mathrm{Pb}-\mathrm{Hf}$ systematics, geochemistry and constraints on crustal evolution," Precambrian Research, vol. 326, pp. 58-83, 2019.

[26] S. W. Liu, Y. J. Lü, Y. G. Feng et al., "Zircon and monazite geochronology of the hongqiyingzi complex, northern Hebei, China," Geological Bulletin of China, vol. 26, no. 9, pp. 1086-1100, 2007.

[27] F. Wang, F. K. Chen, W. Siebel, S. Q. Li, P. Peng, and M. Zhai, "Zircon $\mathrm{U}-\mathrm{Pb}$ geochronology and $\mathrm{Hf}$ isotopic composition of the hongqiyingzi complex, northern Hebei province: new evidence for paleoproterozoic and late paleozoic evolution of the northern margin of the north China raton," Gondwana Research, vol. 20, pp. 122-136, 2011.

[28] H. C. Wang, H. Chu, and Z. Q. Xiang, "The hongqiyingzi group in the chongli-chicheng area, northern margin of the north China craton: a suite of late paleozoic metamorphic complex," Earth Science Frontiers, vol. 19, no. 5, pp. 100-113, 2012. 